\section{Confirmation on the immunogenicity assay used in the SB4 phase III study: response to the comments by Meacci et al}

We appreciate Meacci $e t a l^{1}$ for the comments on the anti-drug antibody (ADA) detection methods.

As noted by Meacci et al, the Meso Scale Discovery (MSD) electrochemiluminescence (ECL) bridging assay (Maryland, USA) was used in the SB4 Phase III study to detect ADAs. ${ }^{2}$ The bridging assay format relies on the characteristics of ADA to crosslink two drug molecules conjugated to a capture and a detection label. Due to the methods employed in the ECL bridging technology, ECL is more sensitive and has higher drug tolerance compared with ELISA or surface plasmon resonance assay. ${ }^{3}$ Furthermore, in order to facilitate detection of ADA, the drug-ADA immune complexes in our study samples were dissociated through acid dissociation, ${ }^{4}$ leading to an improved drug tolerance.

According to the biosimilar guidelines ${ }^{5-7}$ the goal of the clinical immunogenicity assessment is to evaluate potential differences between the proposed product and the reference product in the incidence and severity of human immune responses. It is recommended that the sponsor should use assays that are sensitive and capable of detecting all antibodies induced against the product in all antibody-positive patients. For the reasons explained above, ECL was employed in our study as well as most of other biosimilar studies ${ }^{8-11}$ to detect any difference in immunogenicity between the biosimilar and reference product. Overall, as pointed out by Meacci et al, the use of ECL may have contributed to the higher incidence of ADA in our study compared with main literature data. ${ }^{12-14}$

We hope that the details and confirmation on the assay methods provide the readers of Annals of the Rheumatic Diseases additional reference for the immunogenicity data in our study.

\section{Paul Emery, ${ }^{1,2}$ Jiři Vencovský, ${ }^{3}$ Jung Won Kang, ${ }_{1}^{4}$ Jeehoon Ghil ${ }^{4}$}

${ }^{1}$ Leeds Institute of Rheumatic and Musculoskeletal Medicine, University of Leeds, UK ${ }^{2}$ NIHR Leeds Musculoskeletal Biomedical Research Unit, Leeds Teaching Hospitals NHS Trust, Leeds, UK

${ }^{3}$ Institute of Rheumatology, Prague, Czech Republic

${ }^{4}$ Samsung Bioepis Co., Ltd. Incheon, Republic of Korea

Correspondence to Professor Paul Emery, Leeds Institute of Rheumatic and Musculoskeletal Medicine, University of Leeds, Chapel Allerton Hospital, Chapeltown Road, Leeds LS7 4SA, UK; p.emery@leeds.ac.uk

Competing interests None declared.

Provenance and peer review Commissioned; internally peer reviewed.

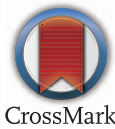

To cite Emery P, Vencovský J, Kang JW, et al. Ann Rheum Dis 2016;75:e40.

Accepted 22 April 2016

Published Online First 17 May 2016

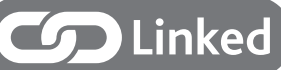

- http://dx.doi.org/10.1136/annrheumdis-2016-209665

Ann Rheum Dis 2016;75:e40. doi:10.1136/annrheumdis-2016-209696

\section{REFERENCES}

1 Meacci F, Manfredi M, Infantino M, et al. Anti Etanercept and anti SB4 antibodies detection: impact of the assay method. Ann Rheum Dis 2016:75:e39.

2 Emery P, Vencovsky J, Sylwestrzak A, et al. A phase III randomised, double-blind, parallel-group study comparing SB4 with etanercept reference product in patients with active rheumatoid arthritis despite methotrexate therapy. Ann Rheum Dis 2015; Published Online First 6 Jul 2015. doi:10.1136/annrheumdis-2015-207588

3 Liang M, Klakamp SL, Funelas C, et al. Detection of high- and low-affinity antibodies against a human monoclonal antibody using various technology platforms. Assay Drug Dev Technol 2007;5:655-62.

4 Patton A, Mullenix MC, Swanson SJ, et al. An acid dissociation bridging ELISA for detection of antibodies directed against therapeutic proteins in the presence of antigen. J Immunol Methods 2005;304:189-95.

5 European Medicines Agency. Guideline on similar biological medicinal products containing biotechnology-derived proteins as active substance: non-clinical and clinical issues. (EMEA/CHMP/BMWP/42832/2005). 2015. http://www.ema.europa. eu/docs/en_GB/document_library/Scientific_guideline/2015/01/WC500180219.pdf (20 Apr 2016).

6 European Medicines Agency. Guideline on Immunogenicity assessment of biotechnology-derived therapeutic proteins. (EMEA/CHMP/BMWP/14327/2006 Rev. 1). http://www.ema.europa.eu/docs/en_GB/document_library/Scientific_guideline/ 2015/10/WC500194507.pdf (20 Apr 2016).

7 Food and Drug Administration. Guidance for Industry: Scientific Considerations in Demonstrating Biosimilarity to a Reference Product. 2015. http://www.fda.gov/ downloads/DrugsGuidanceComplianceRegulatoryInformation/Guidances/ UCM291128.pdf (20 Apr 2016).

8 Udata C, Yin D, Cai C, et al. Immunogenicity Assessment of PF-06438179, A Potential Biosimilar to Infliximab, In Healthy Volunteers. Ann Rheum Dis 2015;74: (Suppl 2):702.

9 Yoo DH, Hrycaj P, Miranda P, et al. A randomised, double-blind, parallel-group study to demonstrate equivalence in efficacy and safety of CT-P13 compared with innovator infliximab when coadministered with methotrexate in patients with active rheumatoid arthritis: the PLANETRA study. Ann Rheum Dis 2013;72:1613-20.

10 Kaur P, Kirshnan E, Zhang N, et al. Biosimilar candidate ABP501: immunogenicity results from 2 phase 3 studies. 11th Congress of ECCO; 2016; Amsterdam.

11 Park W, Hrycaj P, Jeka S, et al. A randomised, double-blind, multicentre, parallel-group, prospective study comparing the pharmacokinetics, safety, and efficacy of CT-P13 and innovator infliximab in patients with ankylosing spondylitis: the PLANETAS study. Ann Rheum Dis 2013;72:1605-12.

12 Combe B, Codreanu C, Fiocco U, et al. Etanercept and sulfasalazine, alone and combined, in patients with active rheumatoid arthritis despite receiving sulfasalazine: a double-blind comparison. Ann Rheum Dis 2006;65:1357-62.

13 Keystone EC, Schiff MH, Kremer JM, et al. Once-weekly administration of $50 \mathrm{mg}$ etanercept in patients with active rheumatoid arthritis: results of a multicenter, randomized, double-blind, placebo-controlled trial. Arthritis Rheum 2004;50:353-63.

14 Bathon JM, Martin RW, Fleischmann RM, et al. A comparison of etanercept and methotrexate in patients with early rheumatoid arthritis. $N$ Engl J Med 2000;343:1586-93. 